University of Nebraska - Lincoln

DigitalCommons@University of Nebraska - Lincoln

USDA Forest Service / UNL Faculty Publications U.S. Department of Agriculture: Forest Service -National Agroforestry Center

2011

\title{
Risk maps for targeting exotic plant pest detection programs in the United States
}

\author{
R Magarey \\ Center for Integrated Pest Management, North Carolina State University \\ D Borchert \\ Center for Plant Health Science and Technology \\ J S. Engle \\ North Carolina State University \\ M Colunga-Garcia Michigan State University \\ F Koch \\ North Carolina State University \\ See next page for additional authors
}

Follow this and additional works at: https://digitalcommons.unl.edu/usdafsfacpub

Part of the Forest Sciences Commons

\begin{abstract}
Magarey, R; Borchert, D; Engle, J S.; Colunga-Garcia, M Michigan State University; Koch, F; and Yemshanov, D Canadian Forest Service, Great Lakes Forestry Centre, "Risk maps for targeting exotic plant pest detection programs in the United States" (2011). USDA Forest Service / UNL Faculty Publications. 152. https://digitalcommons.unl.edu/usdafsfacpub/152
\end{abstract}

This Article is brought to you for free and open access by the U.S. Department of Agriculture: Forest Service -National Agroforestry Center at DigitalCommons@University of Nebraska - Lincoln. It has been accepted for inclusion in USDA Forest Service / UNL Faculty Publications by an authorized administrator of DigitalCommons@University of Nebraska - Lincoln. 


\section{Authors}

R Magarey; D Borchert; J S. Engle; M Colunga-Garcia Michigan State University; F Koch; and D Yemshanov Canadian Forest Service, Great Lakes Forestry Centre 


\title{
Risk maps for targeting exotic plant pest detection programs in the United States
}

\author{
R. D. Magarey ${ }^{1}$, D. M. Borchert², J. S. Engle ${ }^{3}$, M. Colunga-Garcia ${ }^{4}$, F. H. Koch ${ }^{5}$ \\ and D. Yemshanov6 \\ ${ }^{1}$ Center for Integrated Pest Management, North Carolina State University, 1730 Varsity Drive, Suite 300, Raleigh, NC 27606 (USA); \\ e-mail: roger.d.magarey@aphis.usda.gov \\ ${ }^{2}$ USDA Animal and Plant Health Inspection Service, Plant Protection and Quarantine Division, Center for Plant Health Science and \\ Technology, 1730 Varsity Drive, Suite 300, Raleigh, NC 27606 (USA) \\ ${ }^{3}$ Department of Plant Pathology, North Carolina State University, 1730 Varsity Drive, Suite 300, Raleigh, NC 27606 (USA) \\ ${ }^{4}$ Center for Global Change and Earth Observations, Michigan State University, 205 Manly Miles Bldg, 1405 S. Harrison Rd., East Lansing, \\ MI 48823 (USA) \\ ${ }^{5}$ Department of Forestry and Environmental Resources, North Carolina State University/USDA Forest Service, Eastern Forest \\ Environmental Threat Assessment Center, 3041 Cornwallis Road, Research Triangle Park, NC 27709 (USA) \\ ${ }^{6}$ Natural Resources Canada, Canadian Forest Service, Great Lakes Forestry Centre, 1219 Queen Street E. Sault Ste Marie, ON P6A $2 E 5$ \\ (Canada)
}

\begin{abstract}
In the United States, pest risk maps are used by the Cooperative Agricultural Pest Survey for spatial and temporal targeting of exotic plant pest detection programs. Methods are described to create standardized host distribution, climate and pathway risk maps for the top nationally ranked exotic pest targets. Two examples are provided to illustrate the risk mapping process: late wilt of corn (Harpophora maydis) and the giant African land snail (Achatina fulica). Host risk maps were made from county-level crop census and USDA Forest Inventory and Analysis data, respectively. Climate risk maps were made using the North Carolina State University-USDA APHIS Plant Pest Forecasting System (NAPPFAST), which uses a web-based graphical user interface to link climatic and geographic databases with interactive templates for biological modelling. Pathway risk maps were made using freight flow allocation data sets to move commodities from 7 world regions to 3162 US urban areas. A new aggregation technique based on the Pareto dominance principle was used to integrate maps of host abundance, climate and pathway risks into a single decision support product. The maps are publicly available online (http://www.nappfast.org). Key recommendations to improve the risk maps and their delivery systems are discussed.
\end{abstract}

\section{Introduction}

In the United States, the post-border detection of non-indigenous plant pests is the responsibility of the United States Department of Agriculture, Animal and Plant Health Inspection Service (USDA APHIS) and its cooperators (Magarey et al., 2010). The Cooperative Agricultural Pest Survey (CAPS), a joint Federal and State program, plays a major role (Wheeler \& Hoebeke, 2001; USDA APHIS, 2003). CAPS has a multi-tiered structure, with national- and state-level committees comprised of representatives from universities, industry and non-governmental organizations, as well as federal and state agencies. The first category of detection activities conducted by CAPS is targeted surveillance, also known as 'Hot zone', 'Risk Point' or 'High Hazard' surveys (Wheeler \& Hoebeke, 2001). These surveys examine high-risk pathways based on the analysis of phytosanitary data, including pest interception and emergency action or violation records. A second set of detection activities conducted by CAPS are pest detection surveys. CAPS committees select national and state survey targets from federal and state sources, including an annually prioritized national list of approximately 50-60 pests. These pests are selected from a larger USDA APHIS pest list using the analytical hierarchy process (AHP) (Saaty, 1994). Expert opinion is used to answer questions regarding pest biology, pathways and impact for each pest. Pests are then prioritized by AHP using criteria weights selected by USDA APHIS program managers or state cooperators. The criteria include environmental impact (e.g. health of native flora, plants of aesthetic value); economic impact (e.g. trade impacts and production costs); and impact on the CAPS program (survey and identification feasibility) (USDA APHIS, 2010b). The CAPS 2011 pest list includes a total of 50 pests, including 30 arthropods, 12 nematodes, 12 pathogens, 4 molluscs and 1 weed (Table 1). Some of the CAPS targets are designated at genus rather than species level because there may be multiple closely related targets with a high degree of risk. The original USDA APHIS pest list was compiled from lists developed by scientific societies (e.g. the American Phytopathological Society) and from USDA APHIS port pest interception records. 
Table 1 Risk maps created for exotic plant pests on the CAPS 2011 AHP prioritized pest list (http://www.nappfast.org/caps_pests/CAPS_Top_50.htm)

\begin{tabular}{|c|c|c|c|c|}
\hline Pest scientific name & Pest common name & $\begin{array}{l}\text { Host map } \\
\text { (number of primary } \\
\text { and secondary hosts) }\end{array}$ & $\begin{array}{l}\text { Climate } \\
\text { map* }\end{array}$ & $\begin{array}{l}\text { Pathway map } \\
\text { (number of FAF } \\
\text { regions and } \\
\text { FAF commodities) }\end{array}$ \\
\hline \multicolumn{5}{|l|}{ Arthropods } \\
\hline Adoxophyes orana & Summer fruit tortrix moth & 12,30 & DD & 4,5 \\
\hline Agrilus biguttatus & Oak splendour beetle & 1,3 & $\mathrm{CM}$ & 4,4 \\
\hline Archips xylosteanus & Variegated golden tortrix & 0,27 & DD & 4,4 \\
\hline Ceroplastes destructor & Soft wax scale & 3,15 & DD & 3,4 \\
\hline Ceroplastes japonicus & Japanese wax scale & 8,26 & No map & 3,4 \\
\hline Chilo suppressalis & Asiatic rice borer & 3,7 & DD & 5,3 \\
\hline Dendrolimus pini & Pine-tree lappet & 1,2 & CM, DD & 3,4 \\
\hline Dendrolimus superans sibiricus & Siberian silk moth & 1,0 & No map & 1,4 \\
\hline Diabrotica speciosa & Cucurbit beetle & 9,57 & DD & No map \\
\hline Helicoverpa armigera & Old world bollworm & 44,28 & $\mathrm{DD}, \mathrm{CE}$ & 4,7 \\
\hline Leucoptera malifoliella & Pear leaf blister moth & 1,14 & DD & 4,4 \\
\hline Lymantria mathura & Pink gypsy moth & 3,20 & $\mathrm{DD}, \mathrm{CE}, \mathrm{HE}$ & 2,4 \\
\hline Monochamus saltuarius & Japanese pine sawyer & 0,4 & DD & 1,4 \\
\hline Monochamus sutor & $\begin{array}{l}\text { Small white-marmorated } \\
\text { longhorned beetle }\end{array}$ & 0,4 & No map & 4,4 \\
\hline Nysius huttoni & New Zealand wheat bug & 1,26 & DD & 1,3 \\
\hline Otiorhynchus dieckmanni & Wingless weevil & 0,6 & DD & No map \\
\hline Oxycarenus hyalinipennis & Cotton seed bug & 2,22 & DD & 5,6 \\
\hline Planococcus minor & Passionvine mealybug & 10,45 & No map & 4,6 \\
\hline Platypus quercivorus & Oak ambrosia beetle & 9,1 & No map & 1,4 \\
\hline Rhynchophorus ferrugineus & Red palm weevil & 3,1 & $\mathrm{DD}$ & No map \\
\hline Spodoptera littoralis & Egyptian cottonworm & 54,22 & DD & 4,7 \\
\hline Spodoptera litura & Cotton cutworm & 42,43 & DD & 6,7 \\
\hline Thaumatotibia leucotreta & False codling moth & 17,17 & CE, DD & 3,6 \\
\hline Tuta absoluta & Tomato leafminer & 3,3 & DD & \\
\hline Unaspis yanonensis & Arrowhead scale & 1,0 & DD & 3,1 \\
\hline \multicolumn{5}{|l|}{ Molluscs } \\
\hline Achatina fulica & Giant African snail & 16,54 & $\mathrm{DD}, \mathrm{CE}, \mathrm{HE}, \mathrm{CM}$ & 4,22 \\
\hline Cernuella spp. & & No map & $\mathrm{CM} \dagger$ & No map \\
\hline Cochlicella spp. & & No map & $\mathrm{CM} \dagger$ & No map \\
\hline Monacha spp. (M. cantiana, M. syriaca) & & No map & $\mathrm{CM} \dagger$ & No map \\
\hline Veronicellidae & & No map & $\mathrm{CM} \dagger$ & No map \\
\hline \multicolumn{5}{|l|}{ Nematodes } \\
\hline Ditylenchus angustus & Rice stem nematode & 1,0 & No map & 3,1 \\
\hline Heterodera cajani & Pigeonpea cyst nematode & 6,0 & No map & 2,2 \\
\hline Heterodera latipons & Mediterranean cereal cyst nematode & 4,3 & No map & 5,2 \\
\hline Heterodera sacchari & Sugar cane cyst nematode & 2,4 & No map & 4,1 \\
\hline Meloidogyne artiellia & British root-knot nematode & 0,24 & No map & 5,2 \\
\hline Meloidogyne citri & Citrus root-knot nematode & 2,2 & No map & 1,1 \\
\hline Meloidogyne donghaiensis & Citrus root-knot nematode & 2,1 & No map & 1,1 \\
\hline Meloidogyne fallax & False Columbia root-knot nematode & 3,11 & No map & 2,2 \\
\hline Meloidogyne fujianensis & Citrus root-knot nematode & 3,0 & No map & 1,1 \\
\hline Meloidogyne indica & Citrus root-knot nematode & 3,0 & No map & 1,1 \\
\hline Meloidogyne jianyangensis & Citrus root-knot nematode & 3,0 & No map & 1,1 \\
\hline Meloidogyne mingnanica & Citrus root-knot nematode & 3,0 & No map & 1,1 \\
\hline Meloidogyne paranaensis & Parana coffee root-knot nematode & 1,4 & No map & 2,1 \\
\hline \multicolumn{5}{|l|}{ Pathogens } \\
\hline Candidatus Phytoplasma australiense & Phytoplasma yellows & 3,7 & No map & 2,3 \\
\hline Candidatus Phytoplasma prunorum & European stone fruit yellows & 2,3 & No map & No map \\
\hline Charala fraxinea & Ash dieback & 1,0 & No map & No map \\
\hline Cronartium flaccidum & Scots pine rust & 1,0 & CM, IM & 3,5 \\
\hline Harpophora maydis & Late wilt of corn & 1,0 & IN & 3,2 \\
\hline
\end{tabular}




\begin{tabular}{|c|c|c|c|c|}
\hline Pest scientific name & Pest common name & $\begin{array}{l}\text { Host map } \\
\text { (number of primary } \\
\text { and secondary hosts) }\end{array}$ & $\begin{array}{l}\text { Climate } \\
\text { map* }\end{array}$ & $\begin{array}{l}\text { Pathway map } \\
\text { (number of FAF } \\
\text { regions and } \\
\text { FAF commodities) }\end{array}$ \\
\hline Phytophthora alni & Alder root rot & 1,0 & No map & 2,3 \\
\hline Phytoplasma AP-MLO & Apple proliferation & 2,7 & No map & No map \\
\hline Raffaelea quercivora & Japanese oak wilt & 1,0 & No map & No map \\
\hline Ralstonia solanacearum Race 3 biovar 2 & Bacterial wilt of potato & 1,1 & IN & No map \\
\hline Xanthomonas oryzae pv. oryzae & Bacterial leaf blight of rice & 1,1 & IN & No map \\
\hline Xanthomonas oryzae pv. oryzicola & Bacterial leaf streak of rice & 1,0 & IN & No map \\
\hline \multicolumn{5}{|l|}{ Weeds } \\
\hline Onopordum acaulon & Horse thistle & No map & $\mathrm{CM}$ & 3,1 \\
\hline
\end{tabular}

*Climate maps: DD, day-degree model; CE, cold exclusion; HE, heat exclusion; IN, infection model; CM, climate match.

$\dagger$ Climate match maps are currently available for Cernuella virgata, Monacha cantiana and Veronicella spp.

USDA APHIS provides information on pest biology, survey methods and risk analyses for many of these targets to help the CAPS program cooperators plan surveys (Nietschke et al., 2008; Magarey et al., 2010). Among the materials produced for decision support are pest risk maps. These maps provide users with spatially explicit information regarding key risk criteria, such as where host density is the greatest, where climatic and other environmental conditions are most suitable, and where a given pest is likely to enter the United States. The potential users of these maps include CAPS committee members, national- and statelevel agricultural and forest health program managers, pest survey specialists and coordinators, as well as researchers.

Ideally, pest risk maps should be created in a standardized way so that users can develop familiarity with the modelling and mapping process. This will facilitate comparisons between pests and improve the ease of interpretation of risk maps. In 2007, USDA APHIS began a project to create, using standardized methods, an individual set of host, climate and pathway risk maps for each of the top 50 pests prioritized annually for the CAPS program. The project has since expanded, and now involves a multi-institution, collaborative team of scientists from the United States and Canada. Two pests were selected as examples for the risk mapping process: a mollusc, Achatina fulica (giant African land snail) (CABI, 2009) and a fungal pathogen Harpophora maydis (maize late wilt) (Molinero-Ruiz \& Melero-Vara, 2010). The 2 species have very different host, climate and commodity associations and thus provide useful contrasts. Achatina fulica is polyphagous and a hitchhiker on may imported commodities, whereas $H$. maydis is a seedborne pathogen and is very host-specific.

Briefly, host maps for the CAPS top 50 pest targets were created through compilation of crop census and forest inventory data. Climate risk maps were created with the NAPPFAST System, a web-based application for bioclimatic modelling (Magarey et al., 2007). Pathway risk maps were derived from trade and freight data based on assumptions made about the commodities associated with each pest and the geographic flow of those commodities. To provide an overall summary risk map (i.e. a single decision-support product) to guide survey efforts, a map aggregation methodology based on Pareto dominance principles (Pareto ranking) was used to create an integrated risk map from a set of maps depicting key individual aspects of pest invasion risk. The risk maps for the top 50 pests developed for the project (Table 1) are disseminated to stakeholders via a publicly available website (http://www.nappfast.org/caps_pests/CAPS_Top_50.htm). In this paper, procedures for generating each type of risk map are described, along with some recommendations for their future improvement.

\section{Generation of risk maps}

\section{Host risk maps}

The host risk map helps users to determine which counties have the highest density of susceptible hosts. Many pests have wide host ranges, and in such cases an aggregation of the risk across all hosts is a particularly useful summarization. Given their need to work efficiently and in a timely manner, decision makers generally do not want multiple, distinct host maps. The host risk map for each CAPS top 50 pest depicts the combined relative density (on a scale of 1-10) of all of its susceptible hosts. The density maps were created in ArcGIS (ESRI, Redland, USA) using crop or forest inventory data as appropriate. Crop acreages for 127 agricultural commodities were obtained at a county resolution from the 2009 US Agricultural Census (USDA-NASS, 2007). County acreage data for a suite of forest tree species were obtained from the Forest Inventory and Analysis (FIA) Program of the USDA Forest Service (http://fia.fs.fed.us) using the Forest Inventory Data Online tool (FIDO version 0.3.0r1). The tree species acreages were derived using data from the most recent inventory year available for each state, which ranged from 1999 to 2007 (except for Oklahoma, where the most recently available inventory data were collected in 1993). A total of 49 forest host layers were created, with all species in a genera grouped together to create a single layer. For each pest, hosts were identified and designated as either primary or secondary, based on information from the USDA APHIS Global Pest and Disease Database (GPDD). The GPDD contains comprehensive pest reports created from APHIS data sources, in addition to literature and 
Internet database sources such as the CABI Crop Protection Compendium (CABI 2009). Host density, the proportion of total host acreage per county, was calculated as follows. Total primary and secondary host acres were combined in a $2: 1$ (primary : secondary) weighted analysis, then divided by the total acres per county and reclassed into 10 classes using the following upper limits: 0, 0.01, 0.025, 0.05, 0.075, 0.1, 0.25, 0.5, 0.75 , 1. Example host risk maps are presented for A. fulica, a polyphagous pest with 16 primary hosts and 54 secondary hosts (Fig. 1A), and H. maydis, a host-specific pest of corn (Fig. 2A).

\section{The NAPPFAST modelling system}

USDA APHIS uses plant hardiness zones to assess climatic suitability in its commodity risk assessments (Magarey et al., 2008). The conterminous United States has 8 of these zones, making climate an important consideration for any national-scale pest detection survey program. Plant hardiness zones, which are based on annual extreme minimum temperature values, are useful for determining the distributions of plant species. However, for determining the distribution of plant pests, more sophisticated modelling approaches exist that incorporate additional weather variables and/or biological processes. A large number of tools (e.g. CLIMEX and CLIMATCH) have been developed to assess climatic suitability for exotic invasive pests (Sutherst et al., 1999; Peacock \& Abbott, 2010; Venette et al., 2010).

In this study, NAPPFAST, a system that employs a web-based graphical user interface which links climatic and geographic databases with interactive templates, was used to create models that yield spatially explicit risk products (Magarey et al., 2007). The NAPPFAST database contains daily weather data sets from 1978 onwards. The weather variables include daily maximum air temperature, minimum air temperature, precipitation, evaporation, relative humidity, radiation, 2.5 and $5.0 \mathrm{~cm}$ daily average soil temperatures, snow depth, and wetness hours. For North America, a weather station database compiles observations from approximately 2000 stations supplied by government and commercial sources, including the National Oceanic and Atmospheric Administration's broadcast system (NOAAPORT) (Russo, 1999). Station data are interpolated at $10 \mathrm{~km}^{2}$ resolution using a multivariate, regression-based interpolation approach that accounts for elevation (Splitt \& Horell, 1998). NAPPFAST also includes daily global $32 \mathrm{k}\left(1024 \mathrm{~km}^{2}\right)$ grid data derived from the National Center for Environmental Prediction (NCEP)

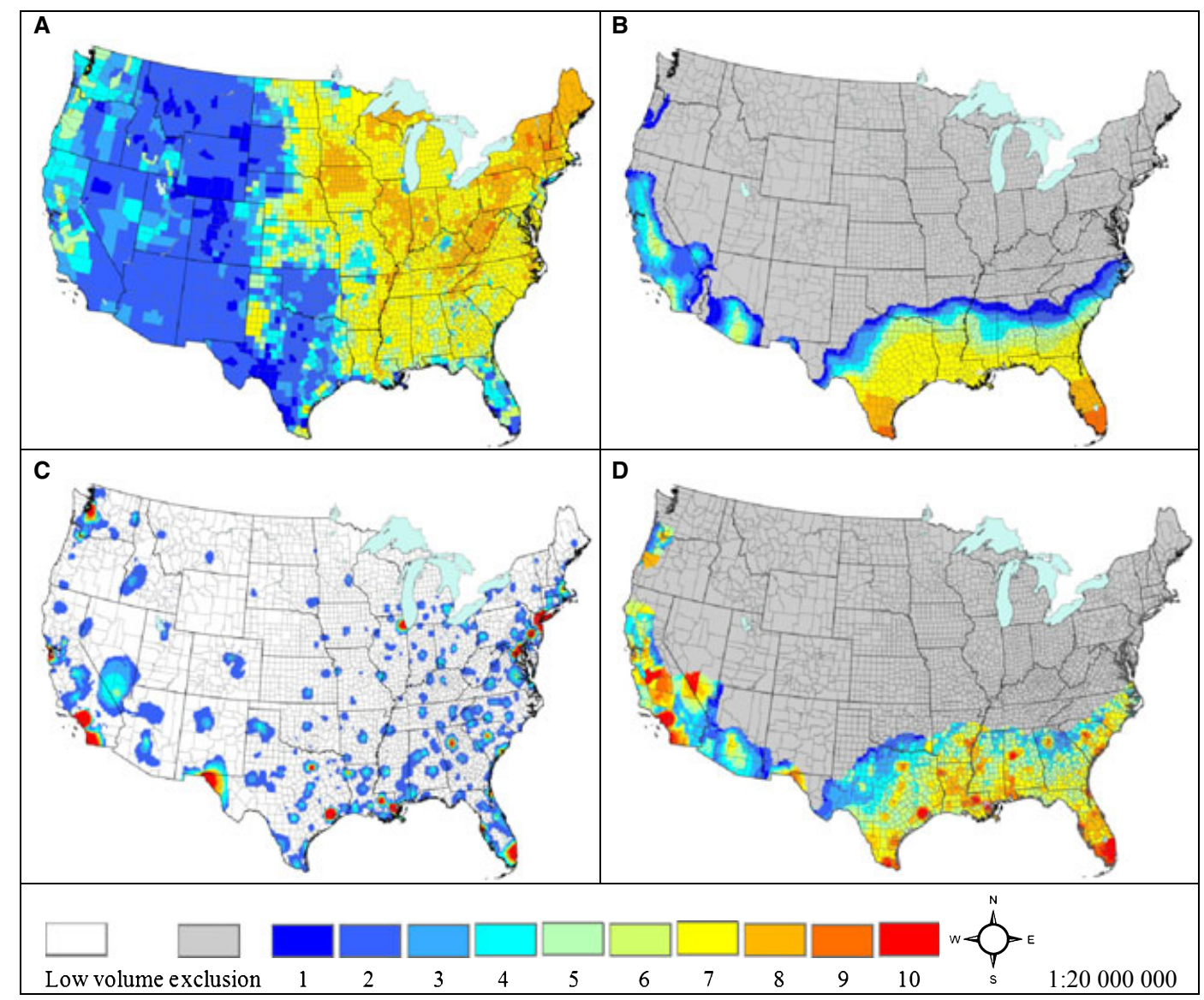

Fig. 1 Risk maps for the giant African land snail, Achatina fulica: (A) susceptible host density; (B) climatic suitability (NAPPFAST map); (C) introduction potential; (D) integrated Pareto risk map. This figure is available in colour online at wileyonlinelibrary.com. 


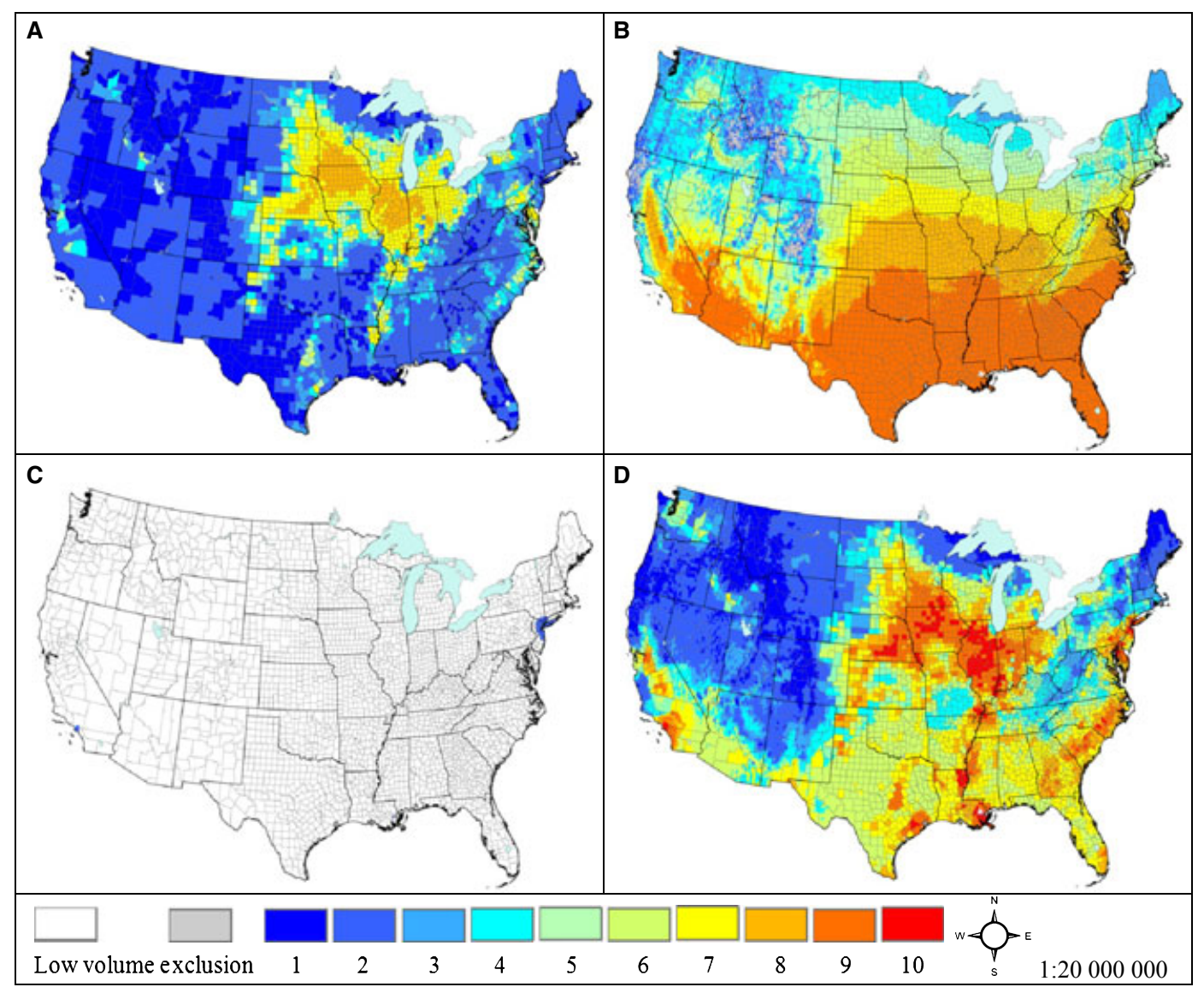

Fig. 2 Risk maps for late wilt of corn, Harpophora maydis: (A) susceptible host density; (B) climatic suitability (NAPPFAST map); (C) introduction potential; (D) integrated Pareto risk map. This figure is available in colour online at wileyonlinelibrary.com.

Reanalysis 2 grid (Kalnay et al., 1996), which can be used to validate pest models with overseas data. NAPPFAST data sets encompass both observed and derived variables. The derived variables, including leaf wetness, evaporation and soil temperature, are calculated using proprietary algorithms. The algorithms used for leaf wetness have been validated in other studies (Magarey et al., 2007). NAPPFAST includes a request function to generate probability and average history maps. Probability maps show the frequency of years meeting specific criteria, as defined by model output variables for a 10 -year period. The average history maps show the average accumulated model output for a 10-year period. Mapped NAPPFAST products can be exported as GeoTIFF images into a geographic information system, where they can be further manipulated into a final climate risk map. The climate risk maps describe the relative climatic suitability (on a scale of 1-10) for pest growth and persistence. Climate maps were created only for those pests influenced by climate. Arthropods were generally modelled through generation potential as estimated by day degrees, and pathogens by the number of infection days per year (see following section). The NAPPFAST System is also used to support the pest risk assessment (PRA) activities and emergency program activities of USDA APHIS, in addition to pest detection needs.
For most weeds and molluscs in the CAPS top 50 list, there were insufficient experimental data to construct deductive models. For these pests, the Bioclimatic Appraisal and Mapping Model (BAMM) tool was used to perform inductive climate matching based on the pests' observed distributions, using a climate pattern-matching approach (Schlegel, 2010).

\section{Climate risk maps for arthropods, pathogens and molluscs}

Degree day models can be useful for risk analysis of exotic arthropods (Baker, 2002) and occasionally for other taxa when developmental requirements are known. For all such pests in the CAPS top 50, a generation potential model was implemented in NAPPFAST using the day degree template (Nietschke et al., 2008). Day degrees were calculated with a single sine curve (Allen, 1976). A requirement for 5 generations per year was arbitrarily chosen as a number which reflects the likelihood that a pest will have sufficient generations to cause economic damage. This requirement was varied to 1 or 2 for uni- or bivoltine pests, respectively. For each pest, individual probability maps were created for the occurrence of 1, 2, 3, 4 and 5 generations per year. All probability maps were added and divided by 5 (or 2 for 
bivoltine pests) to maintain a 10-class scale. A value of 1 represents a low occurrence of multiple pest generations, while a value of 10 indicates that the pest has the degree days required to complete at least 5 generations. The day degree model to predict the potential number of generations per year has been compared with observations from the literature for 21 arthropod pests (Chanelli et al., 2011). The primary causes of model prediction failure in that study were day degrees being non-limiting, insufficient biological data for model parameterization, and insufficient resolution of the grid weather data.

For some pests, survival is determined by exposure to extreme heat or cold. Threshold values above or below which a pest experiences mortality were determined from the GPDD and from treatment manuals (USDA-APHIS, 2010a). A survival model can be created from these thresholds in the NAPPFAST generic template using simple logical statements (Magarey et al., 2007). Based on this survival model, a risk gradient can be computed by generating the frequency of days below or above specific threshold(s). To create a final climate risk map, this survival frequency map was multiplied by -1 and added to the generation potential map.

To illustrate this modelling procedure, representative maps for A. fulica provide an example of a pest with day degree and survival requirements. Achatina fulica requires 2400 day degrees celsius to complete a generation with a base temperature of $12^{\circ} \mathrm{C}$ (Zhou et al., 1998). Days were classified as unsuitable for survival when minimum temperatures were below $-2^{\circ} \mathrm{C}$ and maximum temperatures above $40^{\circ} \mathrm{C}$ (Zhou et al., 1998). The resulting climate risk map shows that $A$. fulica is likely to be a problem only in southern Florida and Texas, although conditions will be favourable in some years across much of the Southern United States (Fig. 1B). A previous study using an ecoregion approach similarly predicted that $A$. fulica establishment would be limited to a small portion of southern Florida (Venette \& Larson, 2004).

Many plant diseases are fungal, and most fungi, with the exception of powdery mildews and some 'wound' pathogens, have significant environmental constraints (Magarey \& Sutton, 2007). While many plant pathogenic processes are temperaturedriven, infection also requires moisture, which is limiting in most terrestrial environments (Magarey et al., 2005b). In addition to fungi, some bacteria also have a moisture requirement to cause infection. To model plant pathogens, NAPPFAST includes a generic infection model based on a temperature-moisture response function (Magarey et al., 2005a; Magarey \& Sutton, 2007). The temperature-response function, commonly used to model crop growth, is scaled to a pathogen's surface wetness requirement to create a simple infection model. Model parameters include the cardinal temperatures for infection $\left(T_{\min }, T_{\mathrm{opt}}, T_{\max }\right)$, leaf wetness requirements (hours per day), rain splash requirement, and degree day initiation.

For each pathogen in the CAPS top 50 list, infection model parameters were obtained from several sources, including the GPDD, Crop Protection Compendium (CABI, 2009), primary literature, culture studies, or by comparison with related organisms (Magarey et al., 2005a). Some pathogens have rain-splash requirements. For example, ascospores of Uncinula necator, the grape powdery mildew, must be splashed from the bark to susceptible new host growth (Gadoury \& Pearson, 1990). As another example, the infection model applied to Guignardia citricarpa has been validated successfully with pest incidence data from South Africa and Australia (Magarey et al., 2009). Harpophora maydis is an example of a CAPS species where an infection model was used to create a climate risk map. The infection model was used without a moisture requirement as the pathogen is soilborne and corn is grown in high-rainfall climates or irrigated fields. The infection model had the following parameters: $T_{\text {min }}=12, T_{\text {opt }}=30, T_{\max }=38^{\circ} \mathrm{C}$, based on various literature reports (Samra et al., 1963; Pecsi \& Nemeth, 1998). The input to the model was average daily soil temperature at $5 \mathrm{~cm}$ depth. Corn is susceptible for 50 days after planting (Sabet et al., 1970). For simplicity, the susceptible period was defined as May-June, based on corn planting statistics (http://www.nass.usda.gov). The model shows that the southern tier of US states would be climatically suitable every year, whereas the Corn Belt would be at risk only in some years (Fig. 2B).

\section{Pathway risk maps}

International transport of goods is one of the most important human-mediated pathways for the dissemination of exotic pests (National Research Council 2002). An understanding of these pathways is critical for the early detection of the CAPS top 50 targets. Manufactured and agricultural goods, including associated packaging material and cargo containers, can harbour exotic pests. Among the several sources of freight transport data available in the United States, the US Department of Transportation's Freight Analysis Framework (FAF) database is one of the most promising to predict the introduction and spread of exotic pests via commodity transport (Colunga-Garcia et al., 2009). The FAF database consists of several data tables for 43 commodity categories of US imports and the within-country flow of US domestic goods (FHWA, 2006b). The FAF includes both monetary values and tonnages, but only the latter was used in this analysis. The FAF database is compiled from multiple data sources, including the Foreign Marine Cargo Statistics (Army Corps of Engineers), in which data gaps are filled using a combination of log-linear modelling and iterative proportional fitting (FHWA, 2006a). The world regions of origin for the imports in FAF are rather coarse (7 world regions), as are the FAF regions within the United States. The latter consist of 66 metropolitan/combined statistical areas and the remaining US territory of entire US states or portions of states.

For each species on the CAPS top 50 list, a pathways risk map was created using pest and FAF trade data (Colunga-Garcia et al., 2009). Step (i) was to obtain the current country distribution of a pest from the GPDD and translate it to FAF region of origin. Step (ii) was to identify the FAF commodity categories associated with the pest, based on data from the GPDD and USDA-APHIS-Plant Protection and Quarantine (PPQ) pest interception records. Colunga-Garcia et al. (2009) outlined equations for (i) allocating imports to US ports of entry (114 regions), and for (ii) allocating the tonnages received at the ports to 3162 urban 
areas, based on FAF domestic commodity flow, urban area population and truck traffic flow. These equations were automated in a statistical package (SAS, Cary, USA). The allocated tonnage for each urban area was assigned to the area's centroid and imported into a geographic information system, ArcGIS (ESRI). Allocated tonnages were kriged from these centroids at a $1-\mathrm{km}^{2}$ pixel resolution to create a graduated risk region for each urban area. Tonnages were classified into 10 divisions, with upper limits as follows: $0,20,100,200,400,500,600,800,900,>1000$ (ktons ${ }^{1}$ ) based on guidelines for commodity risk assessments (USDA-APHIS, 2001). Achatina fulica is potentially imported as a hitchhiker with many FAF commodity categories (examples include cereal grains, other agricultural products, animal products, tobacco, stone, non-metallic minerals, plastics and rubber, furniture and machinery), and because of its widespread distribution (present in Asia, Europe and South America and Africa) (CABI, 2009) it is at high risk of introduction (Fig. 1C). In contrast, $H$. maydis is likely to be carried in only one FAF commodity category (cereal grains), and is only present in 2 world regions (Europe and Asia) (Molinero-Ruiz \& Melero-Vara, 2010) (Fig. 2C). The risk of introduction of H. maydis may actually be greater than this map predicts if the pathogen infiltrates major US seed-production nurseries in South America without being detected.

\section{Integrated Pareto risk maps}

Decision makers may often prefer to work with a single, integrative pest risk map that summarizes the separate risks associated with host density, climate and pathways. In the field of risk analysis, a commonly applied method for integrating multiple risk components is multicriteria decision analysis (Janssen, 1992; Lahdelma et al., 2000; Linkov et al., 2006; Yatsalo et al., 2007). For each criterion, a decision maker provides a fixed numeric or ranked score in cardinal or ordinal scale (Steele et al., 2009), then some multicriteria aggregation method is used to combine the individual criteria scores into an overall ranking (Figueira et al., 2005; Moffett \& Sarkar, 2006). Linear weighted averaging of the multicriteria scores represents one of the simplest and most commonly used aggregation methods (Steele et al., 2009). When constructing an integrated pest risk map, the criteria values (i.e. the values from the component risk maps) for each map location (i.e. each map cell) are standardized to scores, which are then combined by weighted averaging into a continuous metric (Jiang $\&$ Eastman, 2000). In general, each criterion is scored on a fixed scale, for instance from 0 to 10 . Unfortunately, because knowledge with respect to new invasive organisms is usually poor, experts often have difficulty in defining the importance of individual risk criteria (Steele et al., 2009), and use various holistic, constructed (Keeney \& Raiffa, 1976) or triangulatory ranking techniques (Morgan et al., 2000; Florig et al., 2001) to assign the importance weights and reduce biases caused by personal perceptions and lack of knowledge about the individual risk criteria.

\footnotetext{
${ }^{1} 1$ ton $=907 \mathrm{~kg}$.
}

A new technique that does not rely on linear weighted averaging or standardization of the individual criteria uses the principle of Pareto dominance (Yemshanov et al., 2010). Instead of finding weighting coefficients and aggregating criteria scores via linear weighted averaging, integrated multicriteria ranks are delineated as a set of subsequent Pareto frontiers in the criteria space (Fig. 3). In the context of a pest risk map, the points on the outermost Pareto frontier represent those locations (map cells) with the highest aggregated risk combinations, such that no other map locations exhibit combinations of risks higher than those of the locations on the frontier. Ultimately, all map locations can be assigned, based on their risk combinations, to their furthest possible Pareto frontier (the non-dominant set), allowing the locations to be ranked accordingly. The procedure to aggregate multiple risk components into a single risk map uses an algorithm outlined by Goldberg (1989). First, map cells are portrayed as a multidimensional point cloud of individual risk criteria. For example, an aggregation of 3 risk maps would form a 3-dimensional point cloud where each dimension corresponds to an individual risk criterion. The method then finds the initial set of non-dominated points in the cloud (the initial Pareto frontier; Fig. 3), assigns them rank 1, and then removes these elements temporarily. Next, a second non-dominated subset is determined from the rest of the point cloud, assigned rank 2 and temporarily removed, and so forth (Fig. 3). The process is repeated until every point in the cloud has been assigned a Pareto rank. All points that belong to the same Pareto frontier have equal integrated rankings. The ranks assigned to individual points are then referenced back to the original geographic locations (map cells) and plotted as an integrated risk map, which shows the locations' ordinal risk rankings, each representing a subsequent Pareto frontier.

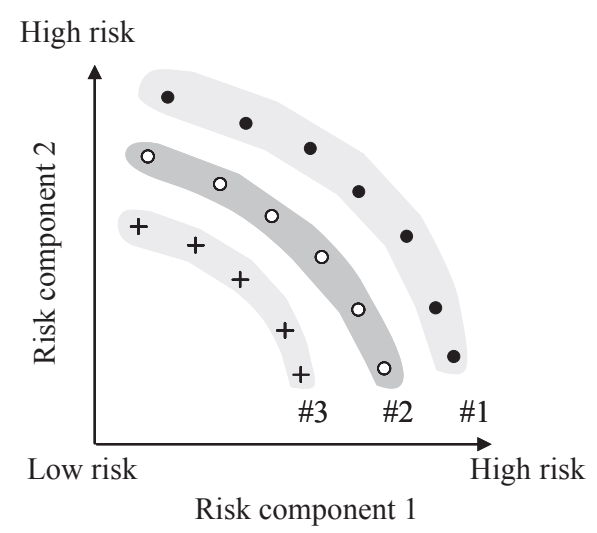

Frontiers based on Pareto dominance:

$$
\begin{gathered}
\text { - } \quad \text { \#1 (non-dominated subset, } \\
\text { dominates sets \#2 and \#3) } \\
\text { - }-\# 2 \text { (dominates \#3, dominated by \#1) } \\
+\quad-\# 3 \text { (dominated by \#1 and \#2) }
\end{gathered}
$$

Fig. 3 The Pareto dominance concept (a two-criteria example) illustrating the principle of integrated multicriteria ranks that are delineated as a set of subsequent Pareto frontiers in the criteria space. 
Conceptually, the analysis is similar to the map aggregation procedure described by Yemshanov et al. (2010).

The final integrated map generated with the Pareto ranking technique map for A. fulica (Fig. 1D) shows the strong influence of importation pathways. In contrast, the risk map for $H$. maydis is driven mainly by host density (Fig. 2D). Stakeholders have indicated that these maps are helpful for targeting surveys, providing a single, integrated risk map. For example, with A. fulica, the New York and Seattle ports and metropolitan areas are at high risk for importation pathways, but are at negligible risk due to the influence of climate.

Overall, the methodology based on the Pareto dominance offers a strategy for addressing the typical lack of knowledge regarding how separate invasion risk components (risk maps of key aspects associated with the introduction and establishment of a new pest) should be combined into a single map. Unfortunately, poor understanding of an organism's behaviour in a new environment is extremely common for recently detected or anticipated invaders, therefore a capacity to generate consistent risk rankings from coarse and imprecise data is essential for time-critical assessments.

\section{Future directions}

The risk maps described provide a standardized method for generating a definitive risk summary for each exotic pest target. In order to improve the risk mapping process, the authors are considering the following recommendations for improving the risk maps.

- Improve ease of use. The current method of distributing risk maps to users (Table 1) relies on an online Microsoft Excel spreadsheet. The risk maps can be downloaded as a pdf, but such maps cannot be integrated with other data sets. A new version of NAPPFAST, which includes role-based access and an online interactive GIS environment, is under development. An early example of this technology is the Pest Information Platform for Extension and Education, which was developed for soybean rust (Isard et al., 2006). Role-based access allows users to see data, products and use tools, depending on their job, geographic location and organization (Sandhu \& Coyne, 1996). Role-based access allows modellers to create risk products and to publish completed risk products, which can then be viewed by users in other roles. For example, program managers and survey specialists can use the Exotic Pest Targeting tool to overlay other data sets, such as survey observations, on top of the risk maps.

- Develop more sophisticated pest models. The current NAPPFAST models generally consider only one biological process (e.g. infection on phenological development). There is potential to develop more complex models that consider factors such as population growth, high or low temperature mortality, moisture, density dependence, latency, host suitability and phenological stage. Examples of models that integrate multiple biological factors include Epiphyas postvitana (light brown apple moth) (Gutierrez et al., 2010). Two examples that use the DYMEX modelling system (Hearne Scientific, Melbourne,
Australia) are Ceratitis capitata (Mediterranean fruit fly) (Yonow et al., 2004) and Magnaporthe grisea (rice blast) (Lanoiselet et al., 2002).

- Improve pathway risk maps. There are a number of areas where pathway risk maps can be improved. The current pathway risk maps relying on the FAF database have relatively coarse geographic resolution and commodity class specification. This situation can be improved by using trade data reported at the country scale, rather than continental or super-regional scale, when evaluating potential pest origins, and by using Harmonized System (HS) commodity classes when evaluating pests' associated commodities (ColungaGarcia M, Magarey RD, Haack RA \& Fowler G, unpublished data). The HS code system has many thousands of commodity classes, compared with only 43 in FAF. A second need is to improve the spatial resolution of the distribution of commodities at the destination which is currently at the resolution of an urban area. In a recent study, ColungaGarcia et al. (2010) showed that commercial land-use data could be used to predict where exotic pest establishment was most likely in an individual urban area. The locations, known as hot spots, were validated with observations from invasions of 3 exotic forest pests.

The spatial and temporal (seasonal) definition of these hot spots can potentially be improved by supplementing trade data sets with phytosanitary and customs databases which describe commodity movement and pest interceptions in even greater detail (Magarey et al., 2010). With this knowledge, the pathway maps can also be improved by a better understanding of the most at-risk commodities, countries and pathways. For example, the Biosecurity Monitoring Group of New Zealand has devised a system of risk units to enable pests and other contaminants to be quantified and compared across pathways (Pearson, 2007). Consequently, risk units could provide a more precise quantification of risk than maps based upon imported tonnages alone. Finally, volumes of imported materials could be calibrated with expected numbers of pest incursions (Koch et al., in press).

- Improve the precision of the map integration technique. The accuracy of the Pareto-based ranking can be further improved by applying a bootstrap permutation procedure. The technique performs multiple Pareto rankings of subsets of the multidimensional point cloud while withholding a certain portion of the points from the analysis, and generates a collection of Pareto-derived risk maps, each characterizing a partially overlapping subset of the original study area. The final ranking is then calculated as the unweighted plurality of the collection of partially overlapping risk maps. The new method would have the capacity to generate partial ranks and incorporate the uncertainties associated with the individual risk criteria. This approach would greatly improve the accuracy of the risk rankings and provide higher-resolution spatial details in the final risk maps.

- Model economic impact. Program managers who make decisions about resource allocation wish to see maps or outputs that describe potential economic impacts rather than risk of 
pest establishment. However, predicting potential pest impacts is extremely complex (Venette et al., 2010) because it includes interactions between pest and host; interactions between supply and demand for affected commodities; costs of pest management or eradication; and impacts of trade and quarantine barriers (Waage \& Mumford, 2008). The development of economic models for plant pests is also impeded by the large number and taxonomic breadth of potential pest targets. Consequently, incorporating an economic impact model into the existing standardized modelling structure would require substantial time and resources to implement. A generic ecological model with components for invasion, spread, control and economic impacts (Waage et al., 2005) could help provide a flexible modelling framework to predict economic impacts. The parameters are designed to allow comparison of a wide range of invasive taxa and economic/ environmental targets.

- Work towards international and interagency cooperation. International cooperation is a critical element of future work for model validation, data sharing and standardization (Venette et al., 2010). Importantly, international and interagency cooperators can provide additional data sets on trade movement, pest or host distribution, and for pest model validation. The need for validation highlights the importance of building high-resolution historical global climate databases, which can be used to validate pest models with observations made as part of routine pest management programs or with site-specific scientific studies. By developing risk maps with standards that cut across agency boundaries, there is much greater potential to share risk map products and develop interoperable models. As an example of interagency cooperation, the USFS Forest Health Technology Enterprise Team (FHTET) creates similar risk maps for recently introduced forest pests such as Sirex noctilio and Agrilus biguttatus (http://www.fs.fed.us/foresthealth/technology/invasive_species. shtml).

In conclusion, a standardized pest risk mapping methodology improves the ease of creation and interpretation of risk maps. Although these products have been developed for the United States, the principles could easily be adopted in other regions or countries. It has taken several years to develop this risk mapping process. The creation of host and climate risk maps for a new species can still take several days' work, including the time taken for literature research. The pathways and Pareto maps currently take longer due to the need to involve several research and computational steps. The authors hope that improvements to the NAPPFAST modelling system will reduce this time commitment through better integration of models and data sets. For example, there are plans to incorporate the pathway modelling algorithms and data directly into NAPPFAST, saving several steps that currently require multiple software tools and analysts. Currently, the CAPS pest prioritization process relies on expert opinion and the analytical hierarchy process. However, the map products which have been generated for over 50 CAPS pests could provide objective data for inclusion into the prioritization process. This approach would be especially helpful for state pest lists, where there may be substantial differences in risk between states. National or state risk rankings for each risk map type can be quickly determined using the zonal statistics function of a geographic information system.

\section{Acknowledgements}

Funding for this project was provided by the US Department of Agriculture, Animal and Plant Health Inspection Service and the Cooperative Agricultural Pest Survey (R. Magarey, D. Borchert, J. Engle); US Department of Agriculture, Cooperative State Research, Education, and Extension Service, National Research Initiative grant 2006-55605-16658 (M. Colunga-Garcia); Research Joint Venture Agreements 08-JV-11330146-078 and 10-JV-11330146-064 between the US Department of Agriculture, Forest Service, Southern Research Station, Asheville, NC and North Carolina State University (F. Koch); and Natural Resources Canada, Canadian Forest Service (D. Yemshanov). David Prokrym (USDA-APHIS-PPQ-CPHST-PERAL) is thanked for reviewing the document. J. Russo and staff of ZedX inc. are thanked for technical support of NAPPFAST.

\section{Développer des cartes de risque pour cibler les programmes de détection des organismes nuisibles exotiques aux Etats- Unis}

Aux Etats-Unis, les cartes de risque phytosanitaires sont utilisées par la Cooperative Agricultural Pest Prospection pour cibler, dans le temps et l'espace, les programmes de détection des organismes nuisibles exotiques. Les méthodes sont décrites pour créer des cartes de risque normalisées pour les plantes-hôtes, le climat et les filières pour les organismes exotiques classés comme les plus nuisibles au niveau national. Deux exemples sont fournis pour illustrer le processus de cartographie des risques: le flétrissement tardif du maïs (Harpophora maydis) et l'escargot géant africain (Achatina fulica). Les cartes de risque des plantes-hôtes sont faites à partir à partir du recensement agricole au niveau des comtés, et de l'inventaire forestier et des analyses de données de l'USDA, respectivement. Les cartes de risque climatique sont faites en utilisant le programme NAPPFAST (North Carolina State University - USDA APHIS Plant Pest Forecasting System), qui utilise une interface graphique en ligne pour associer les bases de données climatiques et géographiques avec des modèles interactifs pour la modélisation biologique. Les cartes de risque par filière sont faites en utilisant les jeux de données sur la répartition des flux de marchandises provenant de 7 régions du monde vers 3162 zones urbaines américaines. Une nouvelle technique d'agrégation basée sur la loi de dominance de Pareto a été utilisée pour intégrer les cartes de risques liées à l'abondance des planteshôtes, au climat et aux filières dans un outil unique d'aide à la décision. Les cartes sont disponibles librement sur Internet (http://www.nappfast.org). Les principales recommandations pour améliorer ces cartes de risque et les systèmes pour les produire sont discutées. 


\section{Карты риска для целевых программ выявления вредных организмов в США}

В целях пространственного и временного планирования программ выявления чужеродных вредных для растений организмов, в США Кооперативным органом по обследованиям вредных для сельского хозяйства организмов используются карты фитосанитарного риска. Приводится описание методов, позволяющих создать стандартизированные карты распространения хозяев, климата и риска путей распространения наиболее важных в масштабе всей страны вредных организмов. Чтобы проиллюстрировать процесс картирования риска приводятся два примера: позднее увядание кукурузы (Harpophora maydis) и гигантская африканская земляная улитка (Achatina fulica). Карты риска для хозяев были составлены Департаментом сельского хозяйства США (USDA) на основе переписи культур на уровне штатов и аналитических данных инвентаризации лесного хозяйства, соответственно. Силами Университета Северной Каролины - Системы прогноза вредных для растений организмов Службы здоровья животных и растений USDA (NAPPFAST), были составлены карты климатического риска, которые используют сетевой графический интерфейс, позволяющий связать климатические и географические базы данных с интерактивными шаблонами для биологического моделирования. Карты риска путей распространения были созданы с использованием наборов данных грузовых перевозок, в которых отражаются перевозки товаров из 7 областей мира в 3162 городских территорий США. Использовалась новая методика агрегирования, основанная на принципе доминантности Парето, позволяющая объединить карты численности хозяев, климата и рисков путей распространения в единый продукт, обеспечивающий поддержку при принятии решений. Карты находятся в открытом доступе онлайн (http:/www.nappfast.org). В статье рассматриваются также основные рекомендации, позволяющие улучшить карты риска и системы их доставки.

\section{References}

Allen JC (1976) A modified sine wave method for calculating degree days. Environmental Entomology 5, 388-396.

Baker RHA (2002) Predicting the limits to the potential distribution of alien crop pests. In: Invasive Arthropods in Agriculture (Ed. Hallman GJ \& Schwalbe CP), pp. 208-241. Science Publishers, Enfield (US).

CABI (2009) Crop Protection Compendium. CABI, Wallingford (GB).

Chanelli S, Magarey RD, Borchert DM \& Engle JS (2011) NAPPFAST Generation Potential Validation. USDA-APHIS-PPQ-CPHST-PERAL, Raleigh, NC. 11, p http://www.nappfast.org/pest\%20reports/arthropod_ validation.pdf. Acessed Jan 182011.

Colunga-Garcia M, Haack RA \& Adelaja AO (2009) Freight transportation and the potential for invasions of exotic insects in urban and periurban forests of the United States. Journal of Economic Entomology 102, 237 246.

Colunga-Garcia M, Haack RA, Magarey RD \& Margosian M-L (2010) Modeling spatial establishment patterns of exotic forest insects in urban areas in relation to tree cover and propagule pressure. Journal of Economic Entomology 103, 108-118.

FHWA (2006a) Report 1. An Overview of the 2002 Commodity OriginDestination Database: Methodology and Data. http://ops.fhwa.dot.gov/ freight/freight_analysis/faf/faf2_reports/report1.htm [accessed on 18 March 2008]

FHWA (2006b) Freight Analysis Framework (FAF) version 2.2, User Guide. http://www.ops.fhwa.dot.gov/freight/freight\%5Fanalysis/faf/faf2userguide/ faf2userguide.pdf [accessed on 18 March 2008]

Figueira J, Greco S \& Ehrgott M (2005) Multiple Criteria Decision Analysis: State of the Art Surveys. Kluwer Academic, Dordrecht (NL).

Florig HK, Morgan MG, Morgan KM, Jenni KE, Fischhoff B, Fischbeck PS \& DeKay ML (2001) A deliberative method for ranking risks (I): overview and test bed development. Risk Analysis 21, 913-922.

Gadoury DM \& Pearson RC (1990) Ascocarp dehiscence and ascospore discharge in Uncinula necator. Phytopathology 80, 393-401.

Goldberg DE (1989) Genetic Algorithms in Search, Optimization, and Machine Learning. Addison-Wesley, Reading (US).

Gutierrez A, Mills N \& Ponti L (2010) Limits to the potential distribution of light brown apple moth in Arizona-California based on climate suitability and host plant availability. Biological Invasions, 12, 3319-3331.

Isard SA, Russo JM \& DeWolf ED (2006) The establishment of a national pest information platform for extension and education. Plant Health Progress http://www.plantmanagementnetwork.org/pub/php/review/2006/ platform/. doi: 1094/PHP-2006-0915-01-RV.

Janssen R (1992) Multiobjective Decision Support for Environmental Management. Kluwer Academic, Dordrecht (NL).

Jiang H \& Eastman JR (2000) Application of fuzzy measures in multicriteria evaluation in GIS. International Journal of Geographical Information Science 14, 173-184.

Kalnay E, Kanamitsu R, Kistler W, Collins D, Deaven L, Gandin M et al. (1996) The NCEP/NCAR 40-year reanalysis project. Bulletin of the American Meteorological Society 77, 437-471.

Keeney RL \& Raiffa H (1976) Decisions with Multiple Objectives: Preferences and Value Tradeoffs. John Wiley \& Sons, New York (US).

Koch FH, Yemshanov D, Colunga-Garcia M, Magarey RD \& Smith WD (in press) Potential establishment of alien-invasive forest insect species in the United States: where and how many? Biological Invasions. doi: 10.1007/ s10530-010-9883-8.

Lahdelma R, Salminen P \& Hokkanen J (2000) Using multicriteria methods in environmental planning and management. Environmental Management 26, 595-605.

Lanoiselet V, Cother EJ \& Ash GJ (2002) CLIMEX and DYMEX simulations of the potential occurrence of rice blast disease in south-eastern Australia. Australasian Plant Pathology 31, 1-7.

Linkov I, Satterstrom FK, Kiker G, Seager TP, Bridges T et al. (2006) Multicriteria decision analysis: a comprehensive decision approach for management of contaminated sediments. Risk Analysis 26, 61-78.

Magarey RD, Borchert DM \& Schlegel JW (2008) Global plant hardiness zones for phytosanitary risk analysis. Scientia Agricola $\mathbf{6 5}, 54-59$.

Magarey RD, Chanelli S \& Holtz T (2009) Validation Study and Risk Assessment for Guignardia citricarpa (Citrus Black Spot). USDA-APHISPPQ-CPHST-PERAL, Raleigh (US). http://www.nappfast.org/Pest\%20 Reports.htm (accessed Jan 8, 2010).

Magarey RD, Colunga-Garcia M \& Fieselmann DA (2010) Plant biosecurity in the United States: roles, responsibilities, and information needs. BioScience 59, 875-884.

Magarey RD, Fowler GA, Borchert DM, Sutton TB, Colunga-Garcia M \& Simpson JA (2007) NAPPFAST: an internet system for the weather-based mapping of plant pathogens. Plant Disease 91, 336-345. 
Magarey RD, Seem RC, Weiss A, Gillespie TJ \& Huber L (2005b) Estimating surface wetness on plants. In: Micrometeorology in Agricultural Systems (Ed. Hatfield JL, Baker JM \& Viney MK), pp. 199-226. American Society of Agronomy, Madison (US).

Magarey RD, Sutton TB \& Thayer CL (2005a) A simple generic infection model for foliar fungal plant pathogens. Phytopathology 95, 92-100.

Magarey RD \& Sutton TB (2007) How to create and deploy infection models for plant pathogens. In: Integrated Management of Plant Pests and Diseases. Vol. I: General Concepts in Integrated Pest and Disease Management (Ed. Ciancio A \& Mukerji KG), pp. 3-26. Springer, New York (US).

Moffett A \& Sarkar S (2006) Incorporating multiple criteria into the design of conservation area networks: a minireview with recommendations. Diversity and Distributions 12, 135-137.

Molinero-Ruiz ML \& Melero-Vara JM (2010) Cephalosporium maydis, the cause of late wilt in maize, a pathogen new to Portugal and Spain. Plant Disease 94, 379.

Morgan KM, Flogig HK, de Kay ML \& Fischbeck PS (2000) Categorizing risks for risk ranking. Risk Analysis 20, 49-58.

National Research Council (2002) Predicting Invasions of Nonindigenous Plants and Plant Pests. National Academy Press, Washington (US).

Nietschke BS, Borchert DM, Magarey RD \& Ciomperlik MA (2008) Climatological potential for Scirtothrips dorsalis (Thysanoptera: Thripidae) establishment in the United States. Florida Entomologist 91, 79-86.

Peacock D \& Abbott I (2010) The mongoose in Australia: failed introduction of a biological control agent. Australian Journal of Zoology 58, 205227.

Pearson D (2007) Import Risk Analysis: Vehicle \& Machinery. Biosecurity New Zealand, Ministry of Agriculture and Forestry, Wellington (NZ).

Pecsi S \& Nemeth L (1998) Appearance of Cephalosporium maydis Samra Sabet and Hingorani in Hungary. Mededelingen Faculteit Landbouwkundige en Toegepaste Biologische Wetenschappen, Universiteit Gent $\mathbf{6 3}$, 873-877.

Russo JM (1999) Weather forecasting for IPM. In: Emerging Technologies for Integrated Pest Management: Concepts, Research, and Implementation (Ed. Kennedy GG \& Sutton TB), pp. 453-473. APS Press, St Paul (US).

Saaty TL (1994) Fundamentals of Decision Making and Priority Theory with the AHP. RWS Publications, Pittsburgh (US).

Sabet KA, Zaher AM, Samra AS \& Mansour IM (1970) Pathogenic behaviour of Cephalosporium maydis and C. acremonium. Annals of Applied Biology 66, 257-263.

Samra AS, Sabet KA \& Hingorani MK (1963) Late wilt disease of maize caused by Cephalosporium maydis. Phytopathology 53, 402-406.

Sandhu RS \& Coyne EJ (1996) Role-based access control models. Computer 2, 38-47.

Schlegel JW (2010) A Description of BAMM, The Bio-Environmental Appraisal and Mapping Model (formerly the Climate Matching Tool). A NAPPFAST User Manual. http://www.nappfast.org North Carolina State University, Raleigh (US)
Splitt M \& Horell J (1998) Use of multivariate linear regression for meteorological data analysis and quality assessment in complex terrain. Preprint from Tenth Meteorological Observations and Instrumentation, Phoenix, Arizona, January 11-16.

Steele K, Carmel Y, Cross J \& Wilcox C (2009) Uses and misuses of multicriteria decision analysis (MCDA) in environmental decision making. Risk Analysis 29, 26-33.

Sutherst RW, Maywald GF, Yonow T \& Stevens PM (1999) CLIMEX: Predicting the Effects of Climate on Plants and Animals. CSIRO, Collingwood, Australia.

USDA-APHIS (2001) Guidelines for Pathway-Initiated Pest Risk Assessments, Version 5.1. United States Department of Agriculture, Animal and Plant Health Inspection Service, Plant Protection Quarantine. Riverdale (US).

USDA APHIS (2003) CAPS Program Guidebook. United States Department of Agriculture, Animal and Plant Health Inspection Service, Plant Protection Quarantine, Riverdale (US).

USDA-NASS (2009). 2007 Census of Agriculture. http://www.agcensus.usda. gov/Publications/2007/Full_Report/index.asp.

USDA-APHIS (2010a) Non-Chemical Treatment - Cold Treatment. United States Department of Agriculture, Animal and Plant Health Inspection Service, Plant Protection Quarantine, Riverdale (US).

Venette RC \& Larson M. (2004) Mini Risk Assessment, Giant African Snail, Achatina fulica Bowdich (Gastropoda: Achatinidae). Department of Entomology, University of Minnesota, St Paul (US)

Venette RC, Kriticos DJ, Magarey RD, Koch FH, Baker RHA et al. (2010) Pest risk maps for invasive alien species: a roadmap for improvement. BioScience 60, 349-362.

Waage JK, Fraser RW, Mumford JD, Cook DC \& Wilby A (2005) A New Agenda for Biosecurity. Defra, London (GB).

Waage JK \& Mumford JD (2008) Agricultural biosecurity. Philosophical Transactions of the Royal Society B 363, 863-876.

Wheeler AG \& Hoebeke ER (2001) A history of adventive insects in North America: their pathways of entry and programs for their detection, pp. 3-15. Detecting and Monitoring of Invasive Species. Proceedings of the Plant Health Conference 2000, 24-25 October 2000. USDA-APHIS, Raleigh (US)

Yatsalo BI, Kiker GA, Kim J, Bridges TS, Seager TP, Gardner K et al. (2007) Application of multicriteria decision analysis tools to two contaminated sediment case studies. Integrated Environmental Assessment and Management 3, 223-233.

Yemshanov D, Koch FH, Ben-Haim Y \& Smith WD (2010) Detection capacity, information gaps and the design of surveillance programs for invasive forest pests. Journal of Environmental Management 91, 25352546.

Yonow T, Zalucki MP, Sutherst RW, Dominiak BC, Maywald GF et al. (2004) Modelling the population dynamics of the Queensland fruit fly, Bactrocera (Dacus) tryoni: a cohort-based approach incorporating the effects of weather. Ecological Modelling 173, 9-30.

Zhou WC, Cai JF, Chen DN \& Wu YF (1998) Study of viability of the giant African snail in China. Acta Zoologica Sinica 44, 138-143. 